Саша Д. КНЕЖЕВИЋ ${ }^{*}$

Универзитет у Источном Сарајеву Филозофски факултет Пале
Оригинални научни рад

Примљен: 30. 10. 2020.

Прихваћен: 25. 2. 2021.

\title{
ТУРСКИ ЈУНАЦИ У ПЈЕСМАМА ТЕШАНА ПОДРУГОВИЋА И ФИЛИПА ВИШЫИЋА
}

\begin{abstract}
У пјесничко-пјевачком корпусу два најзначајнија и најбоља Вукова пјевача присутна је широка лепеза турских јунака. Највећи број њих су, заправо, босански или херцеговачки муслимани што увелико условљава однос пјевача према њима. Компаративном студијом заснованом на имаголошком истраживању покушаћемо кроз начин именовања турских јунака протумачити став наших пјевача о Другом. У овом раду покушаћемо детектовати заједничке ставове о тим ликовима проистекле из личног животног искуства оба пјевача са муслиманским становништвом.
\end{abstract}

Кључне ријечи: Турци, Тешан Подруговић, Филип Вишњић, имагологија, Други, епска пјесма.

Међу студијама о Тешану Подруговићу и Филипу Вишњићу не постоји ниједна која би компаративно анализирала пјесме двојице најзначајнијих пјевача српске народне епске поезије. Логичним се намеће да овакву компаративну студију заснујемо на имаголошком истраживању, јер се у њој према представи Другог настоје дефинисати поетичке специфичности двојице Вукових најбољих и најзначајнијих пјевача. Изразито оскудна сазнања о Тешану Подруговићу и Филипу Вишњићу у највећој мјери дугујемо Вуку Стефановићу Караџићу из чега произлази и став Радмиле Пешић (1984: 5-6):

Вука Стеф. Караџића ако схватимо као зачетника књижевно-историјских и теоријских проучавања српско-хрватске народне књижевности, па и шире, у оквиру европских студија, што он неоспорно и јесте, онда ћемо већ у првим деценијама прошлог столећа сагледати гранитне темеље за изворно проучавање улоге певача у усменом песништву, њихова удела у уметничком поступку грађења песме, једном речи, функције и односа појединца према колективу и колективном стваралаштву. Вукова, једноставним, јасним реченицама изнета драгоцена сазнања из живота средине одакле је потекао, постала су честим навођењем веома позната, али су и дуго остала у суштини несагледана.

\footnotetext{
*sasa.knezevic@ffuis.edu.ba
} 
Како је бављење суштином исконски покретач сваког научног истраживања у овом раду ћемо покушати, користећи оно мало података о нашим пјевачима, разоткрити сличности и разлике у приказивању Турака у њиховим пјесмама.

Иако су Подруговић и Вишњић, можда би их боље било именовати Тешан и Филип јер ово и нису њихова презимена, и по биографији и по пјевању у суштини антиподи, њихове се судбине и опуси преплићу. Понајприје чињеницом да их обојицу Вук среће током своје прве акције на сакупљању народних умотворина у Карловцима и Шишатовцу прољећа 1815. године, али им се и ту путеви мимоилазе, јер је Вишњића Караџић „добавио” након што га „Подруговић остави”. Подруговић је учесник Устанка, један од ратника револуције коју ће опјевати Филип Вишњић, из Буне ће ратник изаћи у „највећем сиромаштву” (Караџић 1986: 394), дочим пјевач рата „чисто се био погосподио” (Караџић 1986: 396). Док, према Љубомиру Зуковићу (2018: 21) „Вишњићеве песме о Првом српском устанку, осим несумњиве уметничке вредности, поседују и изузетан документациони значај”, у Подруговићевим пјесмама имплицитно препознајемо дух устаничког времена, јер је он, према Владану Недићу (1984: 30) у стварање својих јунака уносио „сву своју душу”. Ову констатацију Недић (1984: 31) изриче тумачећи лик Тешановог бесмртног Бошка Југовића, у коме се по њему преплићу традиција, историја: „Не би онда било немогуће да је наш певач довршавао слику косовског јунака сећајући се устаничких барјактара са дринског ратишта", и лични усуд: „Бошка Југовића нико није могао задржати да не оде на Косово. Године 1815, када је избио други устанак, Подруговића нико није могао задржати у Срему. Он је похитао Србији да би стихове о Бошку Југовићу, тек речене Вуку, одмах потврдио и крвљу”, чиме Недић објашњава Вукових сто шиљака који су се увукли под Тешанову кожу на вијест о новој буни.

Вуковски редослијед пјевача потврдио је Владан Недић (1984: 42) судовима: „Најдаровитији Вуков певач био је Тешан Подруговић”, и: „Од Вукових певача најпознатији је Филип Вишњић” (1984: 44). Опште је мјесто да је Вишњић, у најмању руку, „пјевач - спјевач” како га је именовао Љубомир Зуковић (1991: 53), мање или више пјесник, један од родоначелника пјесника епских пјесама из друге половине 19. вијека до данашњих дана, а да је Подруговић, „Певач кога је Вук највише ценио”, свакако најзначајнији певач који прича, „врстан интерпретатор, али и импровизатор” (Матицки 1980: 177), или „врхунски везани импровизатор” (Митић 2017: 104), па се моћ његових стихова и те како „осетила у такозваном новом певану, до кога је дошло након појаве штампаних збирки, у првом реду Вукових [...] Одјек Подруговићевих песама најјачи је, међутим, у збирци Матице хрватске: скоро целе његове текстове, нарочито оне о Марку Краљевићу, певачи су знали напамет” (Недић 1984: 40).

Све ово потврђује њихов утицај на потоње епске пјеваче и епско пјевање код Срба, очито и других, и њихову кључну улогу у том корпусу. Управо стога они и јесу раздјелница на којој се могу сагледавати специфични феномени српске народне епике какав је и овај. Турски јунаци се у српској народној епској поезији природом ствари приказују као негативци и на себе 
примају хтоничне црте (в. Питулић 2018). Ипак, упркос формулативности народне епике, слика о Другоме није једнообразна и може представљати један од елемената специфичности корпуса појединих пјевача. Отуда је неминовно користити имаголошки приступ у овом истраживању, јер према Јасмини Ахметагић (2018: 16):

У средишту имаголошке пажње јесте нарација о Другом, усвојена у одређеном времену и на одређеном простору. Приче које себи причамо о другима променљиве су, условљене емпиријском реалношћу, културним приликама, идеологијом, па је централни задатак имагологије истраживање тих слика, услова њиховог настанка, прилика у којима оне постају могуће, њихове рецепције и утицаја.

С обзиром на чињеницу да је гуслар као „култна фигура наше народне саборности”, уједно и „изразито етноцентрично биће које непрестано утврђује епски публикум којем и намењује своје песме” (Негришорац 2019: 123), јасно је да је слика другог у његовим пјесмама саображена са сликом коју посједују његови реципијенти, а која је посредно створена и кроз неке пјесме које су раније чули. Отуда се сасвим прикладном може сматрати теза Јасмине Ахметагић (2018: 16-17)

Ако је предмет имагологије сужен на слику друге нације, грађа на којој почивају имаголошка истраживања то никада није: полазећи од конкретног, у своју анализу укључују корпус текстова одређеног аутора, али на подлози оних који, у времену његовог стварања, фигурирају у културном животу, како би утврдили разлог постојања стереотипних слика о другој нацији, проучили реторичко-прагматички потенцијал стереотипа, односно њихову рецепцију.

Дакле, представа о Турцима коју срећемо у пјесмама Тешана Подруговића и Филипа Вишњића проистекла је из традиционалне слике коју садржи епска пјесма, али и из културног миљеа у коме они пјевају своје пјесме, који је суштински заснован на стереотипима, што се недвосмислено односи и на њихово именовање. Снежана Самарџија (2010: 8) сматра да: „Привидну једноставност обиља ликова из фолклорног фонда подупире управо висок степен њихове типизације. Међутим, као и у осталим околностима трајања усмених варијаната, типизираност актера не подразумева тек лако уочавање једне црте или неколико карактеристика, згуснутих у имену”, што добрим пјевачима оставља довољно простора за импровизацију, која јесте највиши стадијум оригиналности у пјевању народне епике, што нас враћа на Елиотову (1963: 57) констатацију:

Једна од чињеница која би могла да избије на светлост дана у току таквог процеса јесте наша тежња да док хвалимо неког песника, подвлачимо оне видове његовог дела у којима он најмање подсећа на било ког другог. У тим видовима или деловима његовог стваралаштва замишљамо да ћемо открити оно што је индивидуална, својствена есенција човека. Са задовољством се задржавамо на ономе по чему се тај песник разликује од својих претходника, а нарочито од својих непосредних претходника; настојимо да пронађемо нешто што се може издвојити да бисмо у том уживали. Међутим, ако приђемо једном песнику без оваквих предрасуда, често ћемо открити да не само најбољи већ и најиндивидуалнији делови његовог дела могу бити они у којима су мртви песници, његови преци, најснажније потврдили своју бесмртност. 
Вук Караџић (1986: 395) је Тешана издвајао по томе што је „песме разумевао и осећао, и мислио је, шта говори”, па је природно осмишљавао своје, од раније пјесми познате, јунаке. С обзиром на то да је он пјевао туђе пјесме на разумијевању и осјећању се заснива његова оригиналност, а то што је мислио шта говори је размјера његове поетике. Сходно томе и именовање јунака је дио његове поетске имагинације, јер: „Име јунака је и у епици вишеслојни знак, који активира одговарајући хоризонт очекивања уз неминовно емотивно ангажовање певача/казивача и слушалаца" (Самарџија 2010: 11). Узевши у обзир тумачење Светозара Кољевића (1998: 296) да „његова личност и судбина објашњавају и његову имагинативну приврженост одређеним темама", јасно је зашто на примјеру његових пјесама настојимо уочити доживљај Другог у српској народној епици.

Сасвим је логично да се у његовим пјесмама именица Турияи најчешће понавља у пјесми Цар Лазар и Царица Милиияа:

„Од Турака нешто и остало"

„Још разгони Турке на буљуке”

„Ђено млого Турци изгинули”

„И Турака дванаест хиљада”.

У истој пјесми се среће и у облику присвојног придјева турски у примјерима:

„Изломљена и Турска и Српска,

Али више Српска, него Турска"

„Милош згуби Турског цар Мурата”.

Етник Турции у овим примјерима је у форми етнонима ${ }^{2}$ и као такав нема никакво додатно стилогено значење. У том облику се много чешће јавља у пјесмама Филипа Вишњића, а стилско маркирање му најчешће омогућавају атрибути који се дају уз њега: „Турци изјелице”, „Турке зулумћаре” (Почетак буне против дахија), „бијесни Турци” (Бој на Лозници, Свети саво и Хасан паша), „Ту су Турци мудри и паметни” (Бој на Лозници). Много значајније је што се код Вишњића појам Турци додатно прецизира различитим демонимима ${ }^{3}$ за што нам је примјер стих из пјесме Почетак буне против дахија „То гледају Турци Бијограци”. Потврду Кољевићевог (1998: 294) исказа „Вишњић је епски пјесник par excellence” у поетизацији етника проналазимо у пјесми Бој на Лозници. Али-паша се над Кураном заклиње да ће повратити Лозницу „моју ђедовину” и за остварење тог плана сакупља војску са лијеве стране Дрине и у њу позива:

\footnotetext{
${ }^{1}$ Сви цитати из пјесама дати су према издањима Сабрана дела Вука Каращића, Београд: Просвета.

${ }^{2}$ Етноним - лингвистички појам којим се означава посебна група властитих именица, које служе као називи за припаднике етничких група, на свим степенима етничке стратификације, од припадника етничких народа, односно етничких нација, до припадника етничких племена и племенских савеза (https://kartaslov.ru).

${ }^{3}$ Демоним - је именица којом се означава становништво одређеног места или области, а изводи се из имена тог места, односно области (https://kartaslov.ru).
} 
„Херцеговце соколове Турке,

Мостаране до мора јунаке;

Па ћу звати млоге капетане,

Крајишнике љуте убојице”.

У овим примјерима појмови Херцеговци, Мостарани и Крајишници, а сви су обједињени етнонимом Турии, представљају демониме, јер означавају муслиманске војнике из ових крајева или града. Градација врхунац достиже у стиховима:

„Седму посла ев’ књигу клетвену

На Бошњаке Турке Мусломане,

На мечете и на све џамије,

На све хоџе и на мујезине".

Видимо да у другом стиху појам Бошњаке нема исту функцију као претходни демоними, па га стога и сам Вишњић додатно образлаже при чему он прелази у форму политонима 4 . У визији и исказу Вишњићевих турских великаша њихова земља је „Босна славна”, али је она и пјевачева постојбина, па стога и не чуди што у пјесми о „земљи и слободи” (в. Килибарда 1976: 80) Лазар Mутап и Арапин апострофира да Вождовој ослобођеној Србији највећа опасност пријети „Од Турака, проклетих Бошњака?”.

Препознавање термина Бошњаци као политонима омогућава нам да друкчије сагледамо однос између зараћених страна на микроплану и зашто, поред Луке Лазаревића и Чупића, баш на помен прекодринца Зеке Буљубаше Вишњић истиче „Њих се боје сви Турци Бошњаци”. Они су разбраћа, а код Вишњића је доминантна веза међу ратницима братска за што најбољи примјер срећемо у пјесми Бој на Салашу:

„Ах, мој брате, Јанко и Вујица, тешко су ми Турци додијали, јер сам, браћо, на крајини љутој, украј Дрине, украј воде хладне" „Браћо моја, Вујица и Јанко” „Ил’ ви пошли ил' не пошли, браћо” „Браћо моја, Вујица и Јанко, И ви браћо, дв'је стотине Срба" „Само, браћо, држ’те се јуначки, Немојте се, браћо, препанути!" „Да сви, браћо, Бога поменемо” „Јоште, браћо, да вам ријеч кажем”.

\footnotetext{
${ }^{4}$ Политоним је именица која служи за означавање појединаца или група по основу њихове званичне припадности неком политичко-територијалном ентитету, на пример по основу држављанства или пребивалишта. Политоним се изводи из имена политичко-територијалног ентитета, на пример из имена државе или неке друге политичко-административне јединице (https://kartaslov.ru).
} 
И пјесми Бој на Лозници Богићевић Анто на шанцу војнике храбри ријечима „О Србини, не бојте се, браћо!”, Лука Лазаревић у логору своју ријеч започиње стиховима „Чујете ли, Српске поглавице! / И ви браћо, мали и велики!”, наставља са лазаревском клетвом којој је пролог стих „Дете, браћо, да се не издамо”, а цијело обраћање војсци поентира са „Дете, браћо, да се не издамо". Да је то манир који Вишњић додјељује свим војводама, потврђује и Милошев узвик „Не бојте се, Србљи, браћо драга!”,

Отуда се сасвим природно чини што пјесму посвећену скоро светачком јунаштву Ивана Кнежевића Филип Вишњић започиње стиховима:
„Војску купи Кулин капетане
Крајишнике Турке невјернике,
Који драгог Бога не познају,
Не имају ни вјере ни душе;
Војску води на богату Мачву".

Овдје су Други, дакле Турци, прије свега Наши, тј. Крајишници, самим тиме много више Други од самих Турака, јер су разбраћа, отпадници - јер „драгог Бога не познају”, изроди - који „Не имају ни вјере ни душе”, па тек на крају непријатељски војници који нападају „богату Мачву”. Сва ова именовања представљају јасне стилске поступке који последњег аеда Европе чине пјеснотворцем чије стваралаштво превазилази границе пуке импровизације и појашњава зашто је баш он „синоним народног песника - збирно име знаних и незнаних твораца српског народног епоса” (Бећковић 2019: 11).

Тешан Подруговић, који је, бар у вуковим збиркама, отемељио не само циклус пјесама о Марку Краљевићу, него у доброј мјери и циклусе хајдучких и ускочких пјесама, и сам је начелно био свјестан да Други није толико далеко и да је та граница веома флуидна. Ипак ће стих „турски клањам, српски Бога молим" испјевати Вишњићев хајдук Ђорђе Чурчија. Устаничке пјесме, географски везане за западну Србију и границу с Босном неминовно намећу домаће муслимане као главне непријатеље српске војске и отуда у пјесми Боја на Салашу наилазимо на стихове:

„Потурицо, Мехмед-капетане, обазри се да се погледамо, да видимо чија је сад Мачва: ил' је твоја ил' ће бити моја, чија ли је од старине била!"

Вербални дио двобоја, саткан од најтежих увреда Филип Вишњић је довео до савршенства у пјесми Бајо Пивљанин и бег Љубовић (в. Кнежевић 2018), а у том духу је дат и овај Чупићев исказ. Облик потурица $a^{5}$ у српској се поезији везује за Његошев Горски вијенаи, али је извијесно био фреквентан у устаничкој Србији, а поготово у Босни Вишњићевог времена. Ипак, у ње-

\footnotetext{
5 Док рјечници српског језика овај појам дефинишу „човјек који је прешао на ислам”, у Школском рјечнику босанског језика Џевада Јахића (1999: 444) поред ове проналазимо још двије детерминације „прост човјек” и „човјек из народа”.
} 
говим стиховима га срећемо само на овом мјесту, са врло јасном функцијом у датом контексту.

Међу Вишњићевим стиховима ћемо, само на два мјеста пронаћи термин Tyре, „Стани, Туре, нијеси утекло!” у пјесми Бој на Мишару, а и то није изречено у боју, него у Босуту гдје након боја одлазе Цинцар Јанко и Лазар Мутап у потрази за Оштроч капетаном и у стиху „Викну паша Туре Дилавера” у пјесми Свети Саво и Хасан-паша, коју Вишњић није сам испјевао. Исти појам изведен из етнонима Турчин, који се може подвести под лингвистички термин пејоративни деминутив ${ }^{6}$ код Тешана Подруговића је најфреквентији облик у именовању јунака из ове етничке групе. Врло је јасно да, чак и ако је до њега дошло у том облику, овакво именовање има јасну функцију и користи се у примјерима када то Турчин и заслужује, као што је случај и са Дилавером. Отуда је овакво именовање редовно у пјесми Марко Краљевић познаје очину сабљу у којој Мустаф-ага чини велики гријех:

„Оде Туре на воду Марицу”

„Пита Марко Туре Мустаф-агу"

„Вели њему Туре Мустаф-ага"

„За што, Туре, да од Бога нађеш!”

„Вели њему Туре Мустаф-ага”

Исто именовање проналазимо и у другим Подруговићевим пјесмама, нпр. Марко Краљевић и Муса Кесеиија „Што гођ Туре пјано говорило” или Марко Краљевић и Ђемо Брђанин „Хоће њега Туре погубити”.

С друге стране управо у поменутој пјесми проналазимо један од прегршт примјера како Тешан Подруговић у својим пјесмама Туркиње опјевава у потпуно друкчијем обрасцу. У стиховима: „Купује га Туркиња ђевојка, / Даје зањга два товара блага", Подруговић показује да Туркиња у овој, као и у неким другим пјесамам не припада Другим, или бар стереотипној слици Другог, него је активно на страни српских јунака. Такав примјер срећемо у пјесми Женидба Стојана Јанковића, у којој се, типично подруговићевски тај однос оваплоћује завршним стиховима:

„И одведе Туркињу ђевојку,

Покрсти је и вјенча је за се

Па је љуби, кадгођ се пробуди".

У пјесми Ришњанин хащија и Лимун трговаи „Туркиња ђевојка” невино страда у сукобу Турака и хајдука гдје се Подруговић приближава Вишњићевом хуманистичком поимању жене, превасходно мајке, експлицираном у стиховима пјесме Станић Станојло:

„Веће, Станко, иди Бијељини,

Те с' састани с Омеровом мајком,

\footnotetext{
${ }^{6}$ Деминутивно-презирни adj. (r. уменьшительно-пренебержѝтельньй) - 1. Који умањује или деминутивни с погрдном или пејоративном обојеношћу (Симеон 1969: 221).
} 
Једна другој јаде изјадите,

Како којој јесте без срдашца."

С правом се можемо запитати „да ли је ово тужбалица покајника или осветника" (Кнежевић 2012: 140), односно да ли је Вишњићева визија Другог понекад тек поглед у сопствени одраз у огледалу из којег је, према Љубомиру Симовићу (1982: 19) израсла једна од најсвјетлијих традиција српске ауторске поезије „то поштовање непријатеља, и саосећање с њим, наћи ћемо касније у песмама Војислава Илића, Шантића и Бојића". Уосталом, упркос свему, Вишњићева љуба Кулин-капетана постаје трагична јунакиња управо у оном „сремачком додатку” пјесме Бој на Мишару и отуда не изненађује посљедњи стих у коме „црче од жалости”, не за својим мужем и недосањаним плијеном, него за цвијетом муслиманске војске чије је страдање побројано у другом извјештају гавранова, који она сама наговјештава када „цикну како љута гуја".

Полемишући о функцији епске традиције у заједници Смиљана Ђорђевић Белић (2010: 148) констатује: „Глас певача вишеструко је присутан у свету песме, а детектује се као повремено иступање из 'епске објективности', остварујући се кроз (ауторске) коментаре на различитим нивоима текста". Ми смо у овом раду управо на једном нивоу покушали показати како различитим именовањем припадника противничке стране два најбоља Вукава пјевача јасно детерминишу властити став према њима. Уочивши да је управо импровизација главно дистинктивно обиљежје које Подруговића чини изузетним, научници су континуирано потврђивали Недићево полазно становиште. Имајући у виду да је још Станислав Винавер (1975: 311) утврдио како: „Величина Филипа Вишњића, знатним делом, следује из те импровизације”, очигледно долазимо до закључка да се на том нивоу граде најважније стилске особености поетског дискурса оба пјевача, а што потврђује и став Бошка Сувајџића да (2010: 90): „Традиција настаје у заједничарству појединца с колективом, епохом, друштвеним регулама и језиком који је пресудно одређују". На тим принципима почивају и ставови према Другом Тешана Подруговића и Филипа Вишњића као најзначајнијих репрезената централне матице те традиције.

\section{ЛИТЕРАТУРА}

Ахметагић 2018: J. Ahmetagić, Teorijsko-metodološke pretpostavke imagologije i njeno preoblikovanje, Приштина, Лепосавић: Баштина, св. 44, 2018, $13-24$

Бећковић 2019: М. Бећковић, Весник промене и песник новине, $y:$ Вишњићу y част, Бијељина: СПКД Просвјета, 11-14.

Винавер 1975: С. Винавер, Критички радови Станислава Винавера, пр. П. Зорић, Нови Сад, Београд: Матица српска, Институт за књижевност и уметност. 
Ђорђевић Белић 2010: С. Ђорђевић Белић, Фигура певача/гуслара: кодирање текста социјалне улоге, $y$ : С. Самарџија (ур.), Ликови усмене књижевноcmu, Београд: Институт за књижевност и уметност, 147-204.

Зуковић 1991: Љ. Зуковић, Српска и хрватска народна епика, Сарајево: Свјетлост.

Зуковић 2018: Љ. Зуковић, Јубилеј Филипа Вишњића, у: Филип Вищюић зборник, Вишеград: Андрићев институт, 37-61.

Елиот 1963: T. S. Eliot, Književni pogledi, Beograd: Prosveta.

Jaхић 1999: Dž. Jahić, Školski rječnik bosanskog jezika, Sarajevo: Ljiljan.

Караџић 1988: В. С. Караџић, Српске народне пјесме, књ. 2, Београд: Просвета.

Караџић 1986: В. С. Караџић, Српске народне пјесме, књ. 3, Београд: Просвета.

Караџић 1986: В. С. Караџић, Српске народне пјесме, къ. 4, Београд: Просвета.

Килибарда 1976: Н. Килибарда, Легенда и поезија, Београд: Рад.

Кнежевић 2012: С. Кнежевић, Вишњићев пјеснички споменик револуцији, Пале: Просвјета.

Кнежевић 2018: С. Кнежевић, Вишњићеве пјесме о двобојима, у: Филип Вишњић - зборник, Вишеград: Андрићев институт, 129-144.

Кољевић 1998: С. Кољевић, Постање епа, Нови Сад: Матица српска.

Матицки 1980: М. Матицки, Певачи, казивачи - песници, Кюижевност $u$ језик, год. XXVII, бр. 2, 169-181.

Митић 2017: К. Митић, Женидба Ајдука Трсколома, у: Д. Перовић (ур.), 200 година сусрета Тешана и Вука, Гацко: Просвјета, 87-106.

Негришорац 2019: В. Негришорац, Вишњићев говор из архајских дубина, $y$ : Вишњићу у част, Бијељина: СПКД Просвјета, 119-128.

Недић 1984: В. Недић, Вукови певачи, Београд: Рад.

Пешић 1984: Р. Пешић, Владан Недић о Вуковим певачима, y: Вукови певачи, Београд: Рад.

Питулић 2018: В. Питулић, Митолошки слој у песми Филипа Вишњића „Почетак буне против дахија", y: Филип Вишьић - зборник, Вишеград: Андрићев институт, 49-62.

Самарџија 2010: С. Самарџија, Усмени жанр и јунак у семантичкој активности, y: С. Самарџија (ур.), Ликови усмене књижевности, Београд: Институт за књижевност и уметност, 7-28.

Симовић 1982: Љ. Симовић, Дупло дно, Београд: Просвета.

Симон 1969: R. Simon, Enciklopedijski rječnik lingvističkih naziva I, Zagreb: Matica hrvatska. https://kartaslov.ru. 21. 10. 2020.

Сувајџић 2010: Б. Сувајџић, Певач и традищија, Београд: Завод за уџбенике. 


\section{Saša D. Knežević}

\section{TÜRKISCHE HELDEN IN DEN LIEDERN VON TEŠAN PODRUGOVIĆ UND FILIP VIŠNJIĆ}

\section{Zusammenfassung}

Eine breite Palette türkischer Helden ist im poetischen Korpus der zwei wichtigsten und besten Vuks Sänger vertreten. Die meisten von ihnen sind eigentlich bosnische oder herzegowinische Muslime, was die Haltung des Sängers ihnen gegenüber stark beeinflusst. Mit der auf Imagologie basierenden vergleichenden Studie, haben wir versucht, die Haltung unserer Sänger gegenüber dem Anderen anhand der Art und Weise der Benennung der türkischen Helden zu interpretieren. In diesem Artikel haben wir versucht, auf einer Ebene zu zeigen, wie die beiden besten Vuks Sänger durch unterschiedliche Benennung der Anhänger der gegnerischen Seite ihre eigene Einstellung zu ihnen klar determinieren. Durch Bemerkung, dass Improvisation das Hauptmerkmal von Podrugović ist, haben die Wissenschaftler Nedićs Position kontinuierlich bestätigt. Die Haltung von Tešan Podrugović und Filip Višnjić als die wichtigsten Vertreter des zentralen Stroms dieser Tradition gegenüber dem Anderen basiert auf diesen Prinzipien. 